\title{
Subaortic stenosis by accessory mitral tissue: Failure of embryonic positioning?
}

Gregorio Laguna, MD, Miriam Blanco, MD, and Yolanda Carrascal, PhD

From the Cardiac Surgery Department, Clinic University Hospital of Valladolid, Valladolid, Spain.

No funding was provided for this work.

Disclosures: Authors have nothing to disclose with regard to commercial support.

Received for publication Dec 10, 2017; revisions received Jan 22, 2018; accepted for publication March 6, 2018; available ahead of print April 25, 2018

Address for reprints: Gregorio Laguna, MD, Cardiac Surgery Department, Clinic University Hospital of Valla-

dolid, Ramón y Cajal Ave, Valladolid 47003, Spain (E-mail: goyotxmed@hotmail.com).

J Thorac Cardiovasc Surg 2018;156:777-9

$0022-5223 / \$ 36.00$

Copyright (C) 2018 by The American Association for Thoracic Surgery

https://doi.org/10.1016/j.jtcvs.2018.03.095

田

Video clip is available online.

Accessory mitral valve tissue (AMVT) is a very uncommon congenital anomaly, more frequently diagnosed in male patients (1.75:1) and during childhood. ${ }^{1}$ AMVT may appear as an incidental finding or may present with symptoms related to left ventricular outflow tract (LVOT) obstruction, such as syncope, arrhythmia, or dyspnea. AMVT originates during embryonic development as a result of anomalous migration of endocardial cushions, folding into the atrioventricular channel and differentiating toward the anterior mitral leaflet (AML). ${ }^{2}$ Its association with other congenital

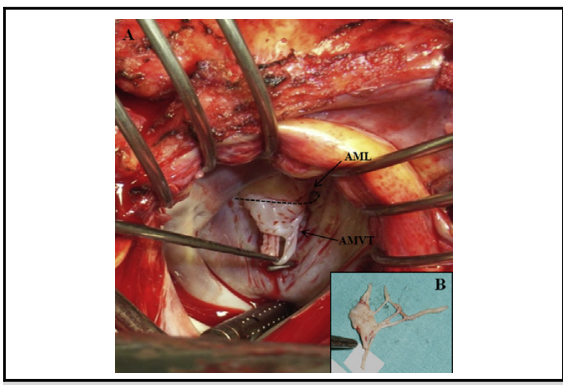

A, Accessory mitral tissue (AMVT) fixed to anterior mitral leaflet (AML). B, AMVT completely resected.

\section{Central Message}

Accessory mitral valve tissue is very uncommon. The patient's echocardiogram showed such tissue and complete obstruction of the left ventricular outflow tract. Mitral valve repair was performed.

See Editorial Commentary page 780.

heart diseases, such as septal defects and subaortic stenosis, is not uncommon. ${ }^{3}$ Prifti and colleagues have described multiple distinct types of AMVT. ${ }^{4}$

We admitted a 48-year-old man with exercise-related syncope. He had undergone a surgical correction of subaortic stenosis 10 years previously. The subaortic membrane was

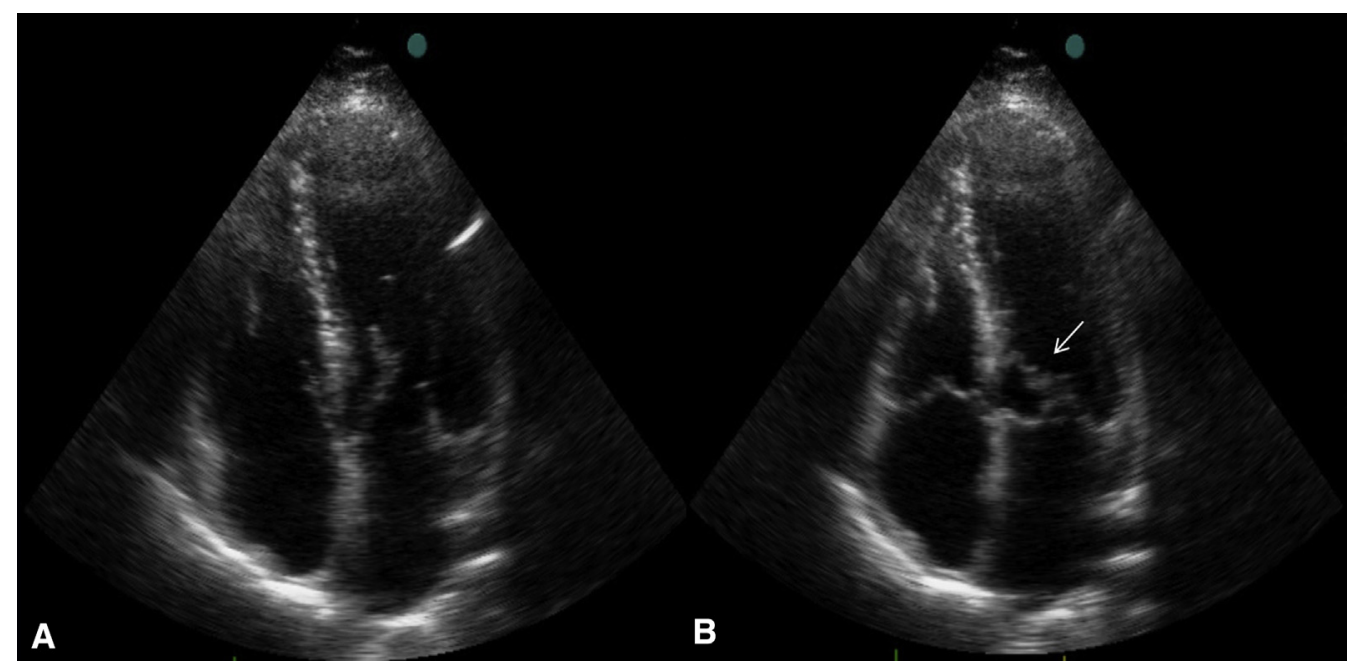

FIGURE 1. A, Transthoracic echocardiogram during diastole. B, Transthoracic echocardiogram showing mild hypertrophy, myxomatous mitral valve without regurgitation or leaflet prolapse, and complete obstruction of left ventricular outflow tract during systole (white arrow). 


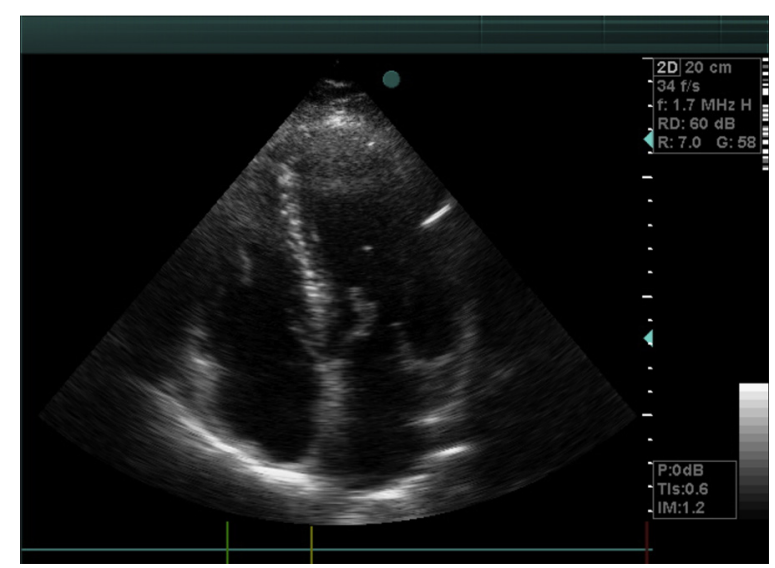

VIDEO 1. Transthoracic echocardiogram shows myxomatous mitral valve without regurgitation or leaflet prolapse and with complete obstruction of left ventricular outflow tract during systole. Video available at: https://www.jtcvs.org/article/S0022-5223(18)30876-6/fulltext.

resected. No echocardiographic findings suggested AMVT diagnosis at that time. At the index admission, an echocardiogram showed mild hypertrophy and myxomatous mitral valve without regurgitation or leaflet prolapse. AMVT led to complete obstruction of LVOT during systole, with a mean gradient of $19 \mathrm{~mm} \mathrm{Hg}$ (Figure 1, A, diastole; Figure 1, $B$, systole, white arrow; and Videos 1 and 2). Mitral valve repair was undertaken. The measured mitral annular diameter was considerably reduced $(23 \mathrm{~mm})$ because of a smaller AML (Figure 2, A). Mobile AMVT (type IIA of Prifti classification $^{4}$ ) was attached to the A2 segment free edge (Figure 2, B). In this case, the AMVT was continued with the free edge of the AML, allowing complete resection of AMVT and an embryonic thickened remnant of chordae tendineae without modifying adequate leaflet coaptation and mitral valve function (Figure 2, C) and without residual mitral regurgitation (Figure 3,A). The postoperative echocardiogram showed no residual systolic anterior motion or mitral regurgitation (Figure 3, B).

AMVT probably corresponded to a remnant of the endocardial cushion that did not fuse properly during the embryonic development, to conform to the AML. Subaortic stenosis masked hemodynamic changes related to AMVT, leading to a delayed diagnosis.

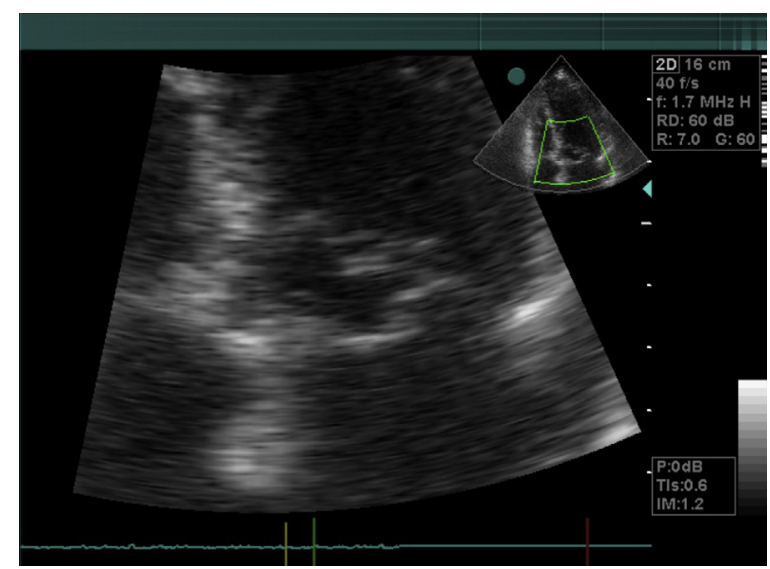

VIDEO 2. Enlarged image of the relevant area in Video 1. Transthoracic echocardiogram during systole shows complete obstruction of left ventricular outflow tract. Video available at: https://www.jtcvs.org/article/S0022-5223(18)30876-6/fulltext. 


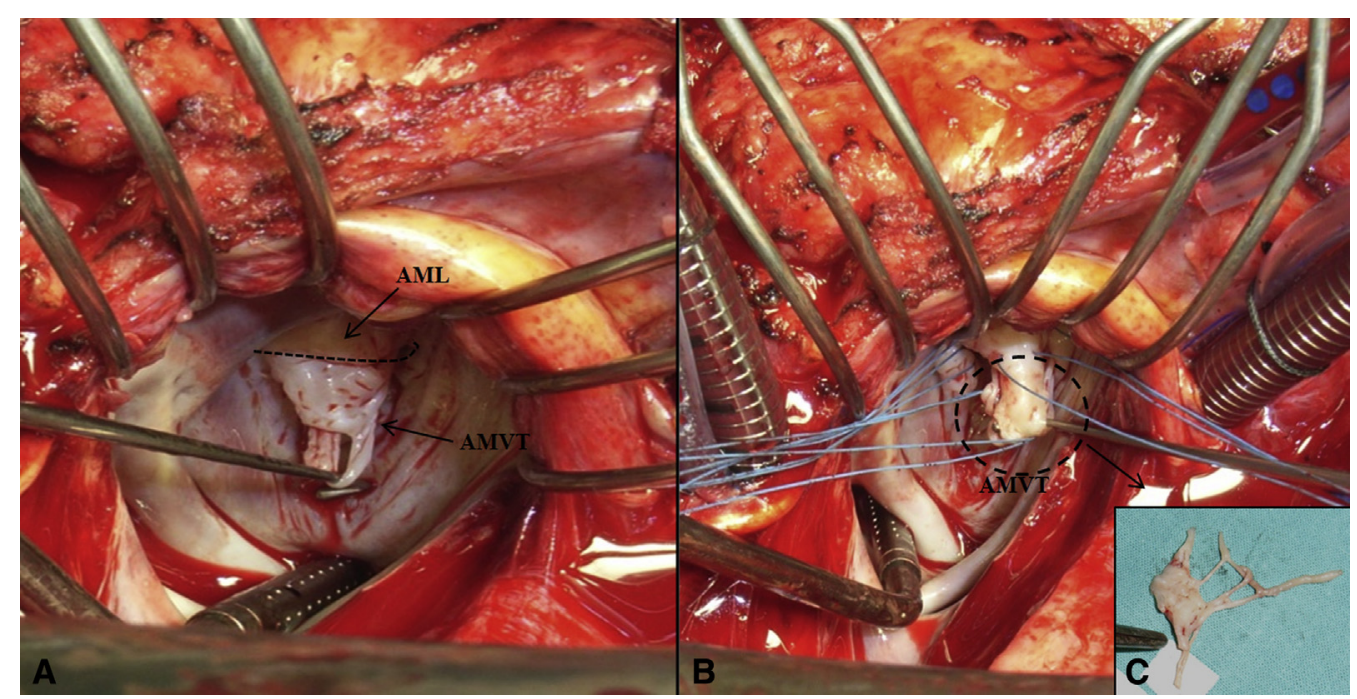

FIGURE 2. A, Surgical image through left atriotomy. The dotted line reveals the boundary between the anterior mitral leaflet $(A M L)$ and accessory mitral valve tissue. B, Surgical image through left ventriculotomy. The dotted line shows the accessory mitral valve tissue anchored to the A2 segment free edge and chordae tendineae. $\mathrm{C}$, Resected accessory mitral valve tissue. AMVT, Accessory mitral valve tissue.

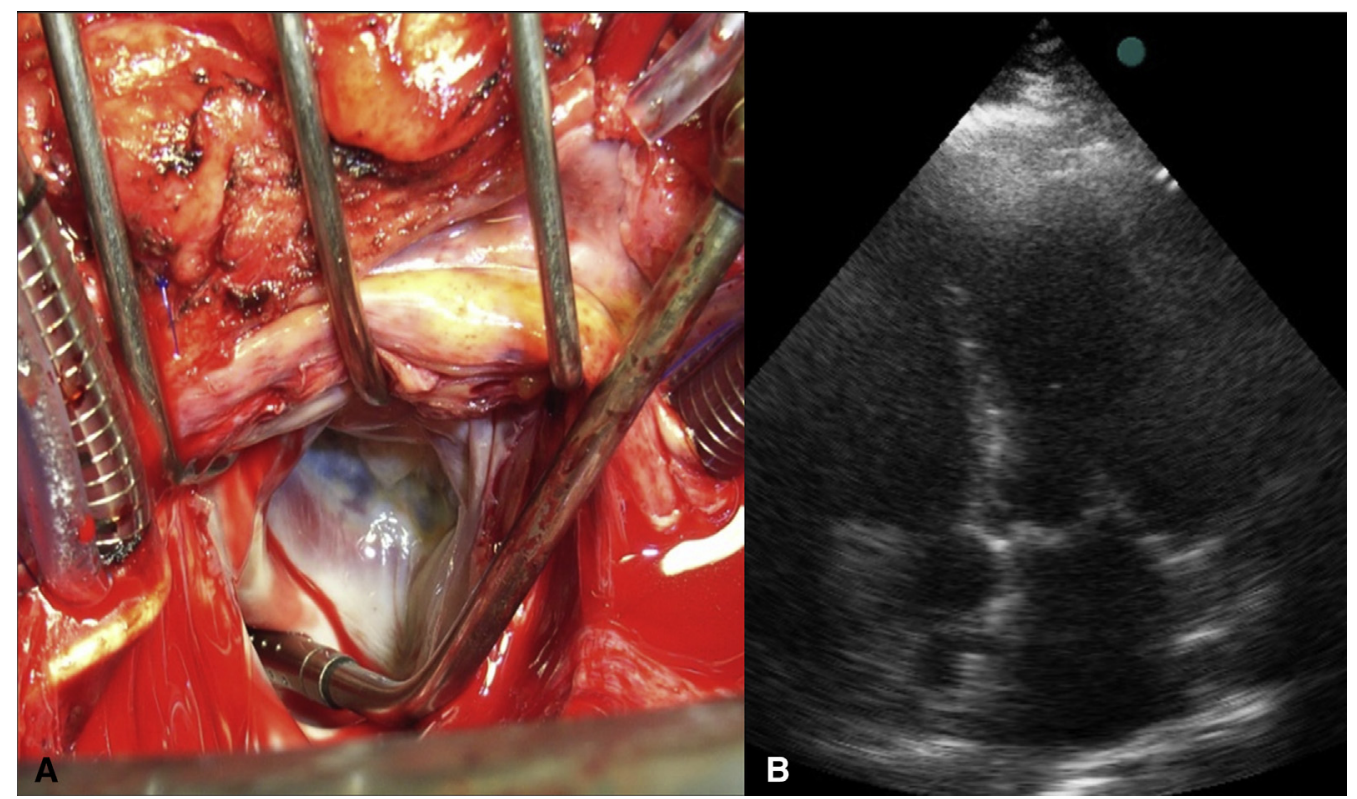

FIGURE 3. A, Surgical image through left atriotomy shows mitral valve repair. Water test showed lack of mitral regurgitation. B, Postoperative transthoracic echocardiogram at discharge shows no residual systolic anterior motion or mitral regurgitation.

\section{References}

1. Manganaro R, Zito C, Khandheria BK, Cusmà-Piccione M, Chiara Todaro MC, Oreto G, et al. Accessory mitral valve tissue: an updated review of the literature. Eur Heart J Cardiovasc Imaging. 2014;15:489-97.

2. Tardy MM, Galvaing G, Sakka L, Garcier JM, Chazal J, Filail M. Embryology of the heart walls [in French]. Morphologie. 2013;97:2-11.
3. Iwata Y, Imai Y, Shin'oka T, Kurosawa H. Subaortic stenosis associated with systolic anterior motion. Heart Vessels. 2008;23:436-9.

4. Prifti E, Bonacchi M, Bartolozzi F, Frati G, Leacche M, Vanini V. Postoperative outcome in patients with accessory mitral valve tissue. Med Sci Monit. 2003;9: RA126-33. 